Original Paper http://ajol.info/index.php/ijbcs http://indexmedicus.afro.who.int

\title{
Ecological effects of oil spill on water and sediment from two riverine communities in Warri, Nigeria
}

\author{
Doris Fovwe OGELEKA ${ }^{1 *}$, Laurelta Esivweneta TUDARARO-AHEROBO ${ }^{2}$ and \\ Felix Ebodaghe OKIEIMEN ${ }^{3}$
}

\author{
${ }^{I}$ Department of Chemistry, Federal University of Petroleum Resources, Effurun, Delta State, Nigeria \\ ${ }^{2}$ Department of Environmental Science, Federal University of Petroleum Resources, Effurun, Delta State, \\ Nigeria. \\ ${ }^{3}$ University of Benin, Geo-Environmental and Climate Change Adaptation Research Centre, Benin City, \\ Nigeria. \\ "Corresponding author; E mail: dorysafam@yahoo.com; Tel: +2348023243514
}

\begin{abstract}
The ecological effects of oil spill in the environment were studied in Warri riverine areas of Ubeji and Jeddo, Delta State, where an oil spill occurred and cleanup or remediation was not carried out for over a year prior to this evaluation. The American Public Health Association (APHA) and the American Society for Testing and Materials (ASTM) methods were employed for the laboratory test for organics [polyaromatic hydrocarbon; total petroleum hydrocarbon (TPH)] and heavy metals in the water and sediment. The results indicated that there were still significant concentrations $(P<0.05)$ of organics indicating hydrocarbon pollution. Mean concentrations recorded for TPH in Ubeji and Jeddo waters were $23.60 \pm 1.18 \mathrm{mg} / \mathrm{L}$ and $29.96 \pm 0.14$ $\mathrm{mg} / \mathrm{L}$ respectively while total PAHs was $0.009 \pm 0.002 \mathrm{mg} / \mathrm{L}$ and $0.008 \pm 0.001 \mathrm{mg} / \mathrm{L}$. Mean concentrations of $\mathrm{TPH}$ in the sediment was $48.83 \pm 1.49 \mathrm{ppm}$ and $1093 \pm 74 \mathrm{ppm}$ respectively while total PAHs was $0.012 \pm$ $0.002 \mathrm{ppm}$ and $0.026 \pm 0.004 \mathrm{ppm}$. Low concentrations were recorded for most of the heavy metals in the water and sediment. Hydrocarbon degrading bacteria (HDB) recorded mean values of $3.86 \mathrm{E}+03$ and $3.44 \mathrm{E}+$ 02 for Ubeji and Jeddo waters, while Hydrocarbon degrading fungi (HDF) recorded mean values of $2.86 \mathrm{E}+03$ and $2.46 \mathrm{E}+02$ respectively. The observed concentrations of hydrocarbons in the study areas should provide the impetus for regulatory surveillance of oil discharged intentionally/unintentionally into the Warri riverine waters and sediment since hydrocarbon released into the environment sorb to the sediment particles where they cause harm to organisms in the sediment and overlying waters.
\end{abstract}

(c) 2016 International Formulae Group. All rights reserved.

Keywords: Crude oil, oil spillage, PAHs, sediment, TPH, water.

\section{INTRODUCTION}

Oil spill is the intentionally and/or unintentionally release of liquid petroleum hydrocarbon into the environment due mainly to anthropogenic activities. Crude oil spillage is a major environmental problem affecting the Niger Delta area of Nigeria. This is occasioned mainly by exploration and exploitation of crude oil, thus exposing the Niger Delta area to environmental degradation. The frequency of oil spill in this region has major adverse effect on aquatic and 
terrestrial organisms (Egborge, 2000; Aisien et al., 2006).

In the Niger Delta, fifty percent (50\%) of oil spills occur due to corrosion, twenty eight percent (28\%) to sabotage and twenty one percent $(21 \%)$ to oil production operations. One percent (1\%) of oil spills occur due to engineering drills, inability to effectively control oil wells, failure of machines, inadequate care in loading and offloading oil vessels, storage and transportation (Jack et al., 2005; Oyem, 2001). In these processes large volumes of hazardous petroleum products are released into the environment (DPR, 2011).

In Nigeria, the Federal Environmental Protection Agency (FEPA), now the Federal Ministry of Environment (FME) stipulates that any operator or owner of a facility is responsible for a spill that impacts the environment. Following this, the Federal Government of Nigeria established the National Oil Spill Detection and Response Agency (NOSDRA), whose duties include detecting and responding to oil spill issues in the country. In the environment guideline and standard for the petroleum industry (EGASPIN), the Department of Petroleum Resources (DPR) stipulates the content of an oil spill contingency plan (OSCP) that should be followed by the oil industry owner in the event of an oil spill (FEPA, 1991; DPR, 2011).

An estimated 9 million - 13 million (1.5 million tons) of oil has been spilled into the Niger Delta ecosystem over the past 50 years; 50 times the estimated volume spilled in Exxon Valdez oil spill in Alaska 1989 (FME, 2006). The Shell Petroleum Development Company (SPDC) since 1989 recorded an average of 221 spills per year in its operational area involving 7350 barrels annually (SPDC, 2006). From 1976-1996, a total of 4647 oil spill incidences spilling approximately $2,369,470$ barrels of oil into the environment of which 1,820,410.5 (77\%) were not recovered. Most of these oil spill incidences in the Niger Delta occur on land, swamp and the offshore environment (Nwilo and Badejo, 2004, 2005a, 2005b; Twumasi and Merem, 2006; Uyigue, 2007).

Oil spill has become a yearly occurrence in the Niger Delta area. In 2009, an oil spill resulting in a fire explosion occurred due to equipment failure in an oil producing facility, which is surrounded by several communities, two (Ubeji and Jeddo) of which were used for this study. The oil spill purportedly released an estimated quantity of $12.56 \mathrm{~m}^{3}(12560 \mathrm{~L})$ of refined petroleum products into waters of Ubeji, Jeddo, Ogunu and Ughoton communities situated in Warri Riverine area (Akpofure et al., 2000).

Oil spilled on water forms a layer on the water surface and prevents oxygen from dissolving in it thus affecting aquatic organisms by interfering with the functioning of various organs of these species and subsequently death (Almeda et al., 2013). Polyaromatic hydrocarbons (PAHs) are chemically quiet stable; thus, due to their lipophilic nature, they can easily penetrate biological membrane and accumulate in organisms (Kanchanamayoon, 2008). Similarly, metals do not biodegrade and are regarded as causing cytotoxic, mutagenic and carcinogenic effects in animals (Hayat et al., 2007; Hussain et al., 2011). Heavy metal contamination may have devastating effects on the ecological balance of the recipient environment and a loss of biodiversity of aquatic organisms (Tawari-Fufeyin, 2007; Ekaye; Yilmaz et al., 2007). Since bottom dwelling organisms cannot easily escape from the detrimental effects of these pollutants, they are considered to be the most affected (Vinodhini and Narayanan, 2008; Ezemonye et al., 2009; Ogeleka et al., 2010).

The aim of this study was to assess crude oil damage to water and sediment in two communities (Ubeji and Jeddo) in Warri Riverine area where an oil spill occurred and no cleanup or remediation was done for over a year prior to this study. The indicating parameters used for this assessment were organics [total petroleum hydrocarbons (TPH), polyaromatic hydrocarbons (PAHs)] 
and inorganic [heavy metals (lead, copper, chromium, iron and zinc)].

\section{MATERIALS AND METHODS Water sampling}

Water samples were collected in triplicates for heavy metal and organics from the two spill points, namely Ubeji and Jeddo rivers. The water samples were stored in $1 \mathrm{~L}$ polyethylene bottles and 1-2 $\mathrm{mL}$ of 1:1 nitric acid (AR) was added to those samples where heavy metals was determined (APHA, 2005). The nitric acid was added to the water samples because it leads to a drop in $\mathrm{pH}$ therefore the loosely bonded ions can be released for determination.

\section{Sediment sampling}

Sediment samples were randomly collected at each spill site. The sediments were collected in polythene bags and dried in laboratory for two weeks to prevent loss of volatile materials while removing moisture. The sediment samples were sieved and fractions with particle diameter less than 2 $\mathrm{mm}$ were retained for subsequent treatment/analysis.

\section{Determination of metals in water}

Water samples were digested using concentrated nitric acid (AR). The sample was mixed and $50 \mathrm{~mL}$ was transferred to a beaker to which $5 \mathrm{~mL}$ concentrated nitric acid was added and brought to a boil on a hot plate to the lowest volume possible (15 to $20 \mathrm{~mL}$ ). Filtration was done after digestion. The filtrate was then diluted to volume with distilled water in a $50 \mathrm{~mL}$ volumetric flask (APHA, 2005). The concentration of heavy metals was determined by running samples on atomic absorption spectrophotometer

(AAS) (Shimadzu 6701F).

\section{Determination of metals in sediment}

One gram $(1.0 \mathrm{~g})$ of the sieved sediment samples was digested in a mixture of perchloric acid, nitric acid and sulphuric acid following standard procedures (IITA, 1984). Filtration of the resulting solution was carried out in order to remove insoluble materials. The filtrate was then made up to mark in a $100 \mathrm{~mL}$ volumetric flask, with doubly distilled water. The metals (lead, copper, chromium, iron and zinc) were analysed using Shimadzu 6701F atomic absorption spectrophotometer. The concentrations were read off from a calibration curve prepared with a set of metal standard solution. All analyses, digestion and spectrophotometric measurements, were carried out in triplicate.

\section{Determination of TPH in sediment}

Five grammes $(5.0 \mathrm{~g})$ of the sediment samples was weighed into a glass extraction bottle and dried with sodium sulphate. The sample was then extracted in a shaking bath with $20 \mathrm{~mL}$ of tetrachloroethylene for 3 hours. The extract was transferred into a clean bottle through a glass funnel stripped with little glass wool and sodium sulphate at the aperture. The eluate was then concentrated to $1-\mathrm{mL}$, placed in a vial and stored in a cool environment. The TPH in the sample was analysed with a GCMS (Agilent 5975C).

\section{Polyaromatic hydrocarbons (PAHs) in water and sediment}

The samples collected for PAHs were dried with sodium sulphate and extracted with dichloromethane (DCM) for 4 hours in a ratio of 1:10 sample:solvent. The subsequent extract was concentrated to $1 \mathrm{~mL}$ by evaporation in a secured fume hood and passed through a fractionating column. The resulting extract was dried with sodium sulphate and placed in clean amber coloured vials rinsed with DCM. An appropriate volume $(1 \mu \mathrm{l})$ was injected into a GC-MS (Agilent 5975C) for the analysis of 16 different PAH components. The GC-MS was calibrated using specific PAHs standards. Standard stock solutions $(1 \mathrm{mg} / \mathrm{mL})$ were prepared by dissolving $10 \mathrm{mg}$ of the desired PAH in $10 \mathrm{~mL} \mathrm{DCM}$ and stored at $20{ }^{\circ} \mathrm{C}$. All working solutions were prepared fresh by serial dilution with DCM. 


\section{Determination of hydrocarbon degrading bacteria and fungi in water and sediment}

One millimeter $(1.0 \mathrm{~mL})$ of the water samples and one gram $(1.0 \mathrm{~g})$ of the sediment samples were measured and serially diluted with sterile normal saline to $10 \mathrm{E}+03$ and $10 \mathrm{E}$ +04 respectively. Mineral salt agar was prepared and sterilized. $0.1 \mathrm{~mL}$ of diluent was inoculated using the pour plate method. 0.1 $\mathrm{mL}$ of $5 \mathrm{mg} / \mathrm{L}$ fungizone was added to a set of plates to inhibit fungi and $0.1 \mathrm{~mL}$ of $5 \mathrm{mg} / \mathrm{L}$ tetracycline solution was added to another set of plates to inhibit bacteria population.

\section{RESULTS}

Two stations (Ubeji and Jeddo) in Warri Riverine area were sampled in triplicate for surface water and sediment. The results of the organics and heavy metal concentrations are presented in Figures $1-2$.

In Ubeji polluted site, the mean total petroleum hydrocarbon (TPH) and polyaromatic hydrocarbons (PAHs) in the water recorded $23.06 \pm 1.18$ and $0.009 \pm$ $0.002 \mathrm{mg} / \mathrm{L}$ respectively. The waters in Jeddo were slightly polluted with petroleum hydrocarbons with mean concentration in the range of $29.96 \pm 0.14 \mathrm{mg} / \mathrm{L}$. The mean value of TPH gives a picture of an environment polluted with petroleum hydrocarbon from the spilled crude oil. The concentrations of heavy metals in the water from Jeddo were relatively low, however, total iron values were higher than the stipulated DPR limit of $1.00 \mathrm{mg} / \mathrm{L}$, a mean concentration of $1.70 \pm 0.03 \mathrm{mg} / \mathrm{L}$ and $1.38 \pm 0.04 \mathrm{mg} / \mathrm{L}$ was recorded for Ubeji and Jeddo respectively (Table 1; Figure 1). The water samples from Ubeji and Jeddo recorded mean HDB counts of $3.86 \mathrm{E}+03 \mathrm{CFU} / \mathrm{mL}$ and $3.44 \mathrm{E}+02 \mathrm{CFU} / \mathrm{mL}$ respectively, while the mean $\mathrm{HDF}$ counts were $2.86 \mathrm{E}+02 \mathrm{CFU} / \mathrm{mL}$ and $2.46 \mathrm{E}+02 \mathrm{CFU} / \mathrm{mL}$ in the above order (Table 1).

In the sediment analysis from Ubeji and Jeddo, the values reported for TPH in this study was $48.83 \pm 1.49 \mathrm{ppm}$ (Ubeji) and 1093 $\pm 74.1 \mathrm{ppm}$ (Jeddo) while concentrations of $0.012 \pm 0.002 \mathrm{ppm}$ and $0.026 \pm 0.004 \mathrm{ppm}$ respectively were recorded for total PAHs. Mean HDB counts obtained in the sediment samples for Ubeji and Jeddo were $4.46 \mathrm{E}+$ $04 \mathrm{CFU} / \mathrm{g}$ and $3.88 \mathrm{E}+03 \mathrm{CFU} / \mathrm{g}$, while the HDF counts recorded $4.36 \mathrm{E}+04 \mathrm{CFU} / \mathrm{g}$ and $4.12 \mathrm{E}+03 \mathrm{CFU} / \mathrm{g}$ in the above order (Table 2).

Although total iron has no DPR regulatory limits in sediments, the concentrations in the sediment environment were quiet high in both locations $1793 \pm 13$ ppm and $1443 \pm 8.14$ ppm respectively (Table $2)$. Besides these, all other heavy metals had concentrations that are within the DPR stipulated range (Figure 2).

Table 1: Mean concentrations of organics, heavy metals and Microbial counts in water around the spill sites.

\begin{tabular}{lccc}
\hline Parameters & \multicolumn{2}{c}{ Spill Location } \\
\cline { 2 - 4 } & DPR Limit, mg/L & Ubeji & Jeddo \\
\hline PAHs, mg/L & N/A & $0.009 \pm 0.002$ & $0.008 \pm 0.001$ \\
TPH, mg/L & 10 & $23.60 \pm 1.18$ & $29.96 \pm 0.14$ \\
Chromium, mg/L & 0.03 & $0.02 \pm 0.01$ & $0.02 \pm 0.01$ \\
Copper, mg/L & 1.50 & $0.03 \pm 0.01$ & $<0.001 \pm 0.00$ \\
Lead, mg/L & 0.05 & $<0.001 \pm 0.00$ & $<0.001 \pm 0.00$ \\
Zinc, mg/L & 1.00 & $0.01 \pm 0.01$ & $0.12 \pm 0.02$ \\
Iron, mg/L & 1.00 & $1.70 \pm 0.03$ & $1.38 \pm 0.04$ \\
HDB, CFU/mL & N/A & $3.86 \mathrm{E}+03$ & $3.44 \mathrm{E}+02$ \\
HDF, CFU/mL & N/A & $2.86 \mathrm{E}+03$ & $2.46 \mathrm{E}+02$ \\
\hline
\end{tabular}


Table 2: Mean concentrations of organics, heavy metals and microbial counts in sediment around the spill sites.

\begin{tabular}{lcccc}
\hline Parameters & \multicolumn{2}{c}{ Sediment, mg/kg dry material } & \multicolumn{2}{c}{ Spill Location } \\
\cline { 2 - 5 } & $\begin{array}{c}\text { DPR Target } \\
\text { value }\end{array}$ & $\begin{array}{c}\text { DPR Intervention } \\
\text { value }\end{array}$ & Ubeji & Jeddo \\
\hline PAHs, $\mathrm{mg} / \mathrm{kg}$ & 1 & 40 & $0.012 \pm 0.002$ & $0.026 \pm 0.004$ \\
$\mathrm{TPH}, \mathrm{mg} / \mathrm{kg}$ & 50 & 5000 & $48.83 \pm 1.49$ & $1093 \pm 74.10$ \\
Chromium, $\mathrm{mg} / \mathrm{kg}$ & 100 & 380 & $1.23 \pm 0.04$ & $1.02 \pm 0.01$ \\
Copper, $\mathrm{mg} / \mathrm{kg}$ & 36 & 190 & $3.26 \pm 0.18$ & $2.68 \pm 0.10$ \\
Lead, $\mathrm{mg} / \mathrm{kg}$ & 85 & 530 & $1.62 \pm 0.05$ & $1.67 \pm 0.39$ \\
Zinc, $\mathrm{mg} / \mathrm{kg}$ & 140 & 720 & $9.10 \pm 0.18$ & $4.16 \pm 0.07$ \\
Iron, $\mathrm{mg} / \mathrm{kg}$ & $\mathrm{N} / \mathrm{A}$ & $\mathrm{N} / \mathrm{A}$ & $1793 \pm 13.0$ & $1443 \pm 8.14$ \\
$\mathrm{HDB}, \mathrm{CFU} / \mathrm{g}$ & $\mathrm{N} / \mathrm{A}$ & $\mathrm{N} / \mathrm{A}$ & $4.46 \mathrm{E}+04$ & $3.88 \mathrm{E}+03$ \\
$\mathrm{HDF}, \mathrm{CFU} / \mathrm{g}$ & $\mathrm{N} / \mathrm{A}$ & $\mathrm{N} / \mathrm{A}$ & $4.36 \mathrm{E}+04$ & $4.12 \mathrm{E}+03$ \\
\hline
\end{tabular}

N/A $=$ Not available

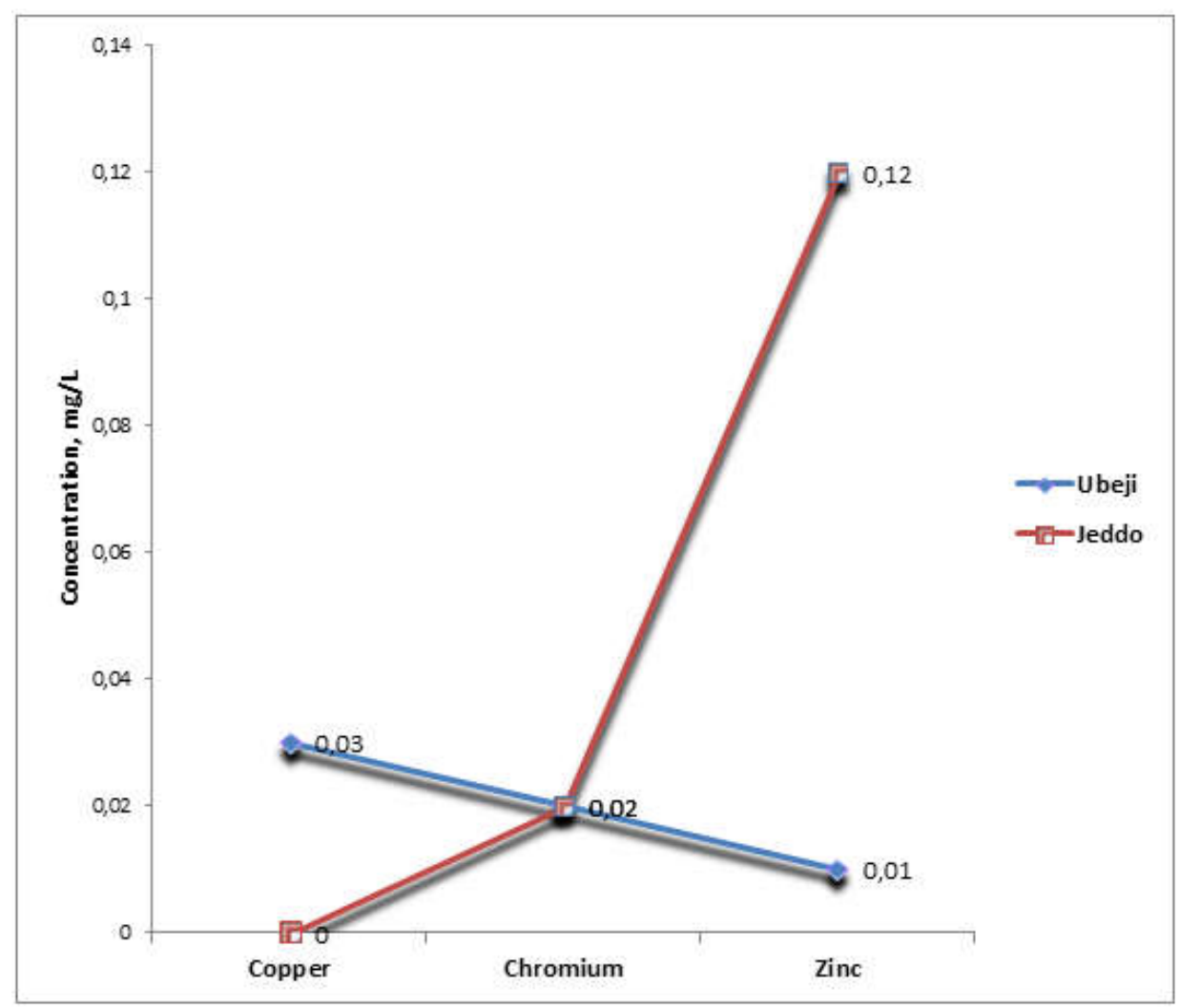

Figure 1: Mean concentrations of some heavy metals in water around the spill sites 


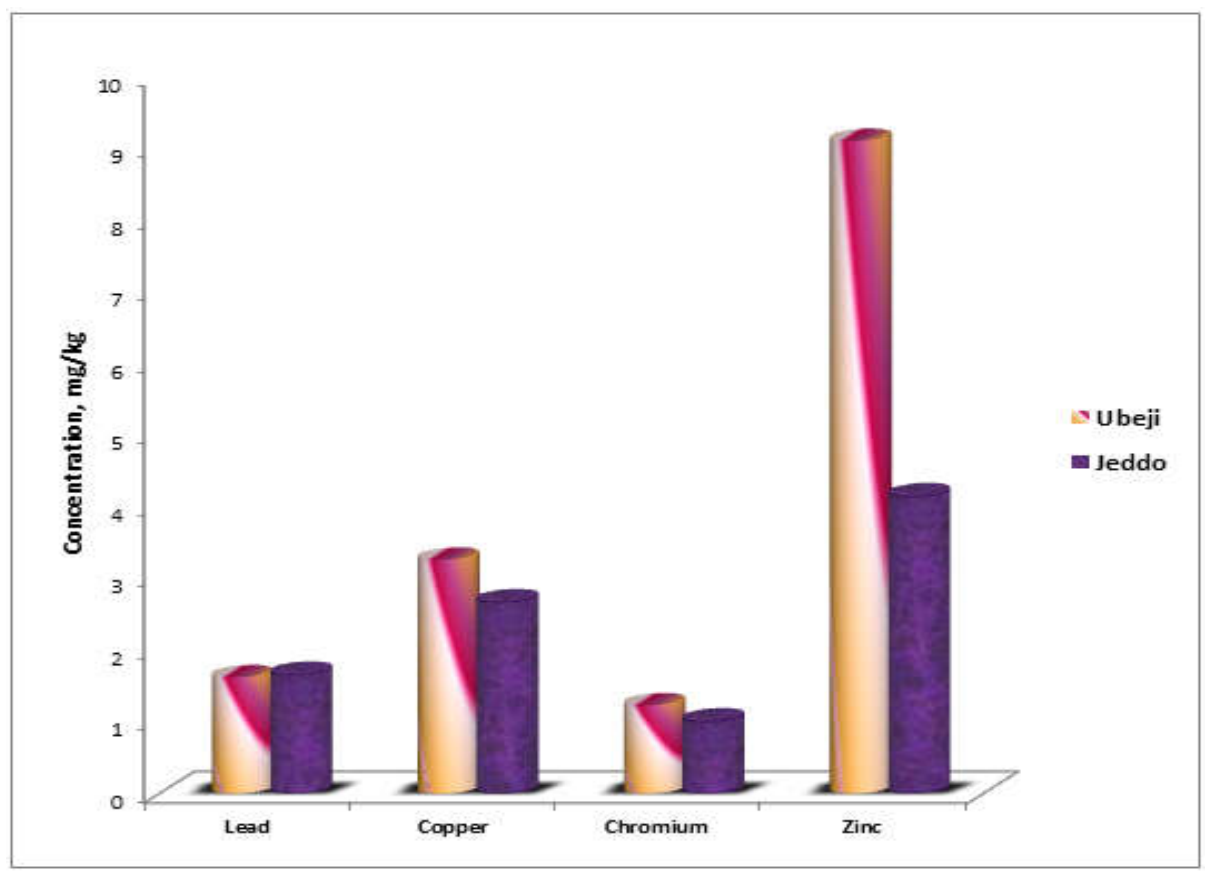

Figure 2: Mean concentrations of some heavy metals in sediment around the spill sites

\section{DISCUSSION}

Ever since the discovery of oil in Nigeria in the 1950s, the country has suffered the negative environmental consequences of oil development. The growth of the country's oil industry, combined with a population explosion and a lack of enforcement of environmental regulations has resulted in substantial damage to the Nigeria's environment, especially in the Niger Delta region, the center of the country's oil industry. Oil spills can have a serious economic impact on coastal activities and on those who exploit the resources of the sea (Ijah and Antai, 2003).

Generally, the toxicity of crude oil is dependent on the nature and type of crude oil, the level of oil contamination, type of environment and the sensitivity of the individual organism (Landis and $\mathrm{Yu}, 2004$ ). Crude oil contains toxic components (petroleum and aromatic hydrocarbons, which could cause acute (lethal) and chronic (sublethal) impacts on organisms. Petroleumbased hydrocarbons can negatively impact marine life at concentrations as low as one part per billion (1 ppb). The fate, behaviour and environmental effects of spilled oil could vary, depending on the type and amount of material spilled. About $30-40 \%$ evaporates in the first $24-48$ hours; these are the most poisonous (toxic) portions, as well as the portions that are the most soluble. The lighter fractions of oil, such as benzene and toluene are highly toxic, but are also volatile and evaporate quickly (Dunnet, 1982; Pyagbara, 2007). Heavier components of crude oil, such as polycyclic aromatic hydrocarbons (PAHs) appear to cause the most damage; while they are less toxic than the lighter volatiles, they persist in the environment much longer.

Oil on the water surface prevents oxygen from dissolving in water, thus leading to fish kills. Similarly, fish, may ingest large amounts of oil and suffer from changes in heart and respiratory rate, enlarged livers, 
reduced growth, fin erosion and a variety of effects at biochemical and cellular levels (Tawari-Fufeyin and Ekaye, 2007).

The hydrocarbon components [polycyclic aromatic hydrocarbons (PAHs)] can affect the chemoreceptors of male organisms thus leading to reproductive impairment (Jack et al., 2005; Kanchanamayoon, 2008). In assessing the impact of crude oil pollution on water bodies, one important consideration is the amount of oil discharged into the water. Where natural degradation is not possible, the process of bioconcentration could lead to build up in the level of hydrocarbon in the waters (Chase et al., 2013).

The HDB and HDF counts were relatively low for effective natural attenuation of hydrocarbon polluted sites by microbes. This could be due to the quantity and components of the crude oil spilled. The high concentration of TPH after one year of spill could have affected the metabolic and physiological functions of the microbes and by extension the biodegradative capabilities (Culbertson et al., 2008). This could also have accounted for the poor bioremediation of the environment by natural attenuation and the observed high values of TPH in both the water and sediment samples.

In this study, the polluted sites had values indicative of hydrocarbon pollution. The results obtained showed that the concentrations of the heavy metals were generally low, although iron was high. Heavy metals have long been recognized as serious pollutants of the aquatic environment. They cause serious impairment in metabolic, physiological and structural systems when present in high enough concentrations. Heavy metals may also affect organisms directly by accumulating in their body or indirectly by transferring to the next trophic level of the food chain since they are non-biodegradable (Heng et al., 2004; Dural et al., 2007; Rauf et al., 2009). However, it have been reported that high concentrations of heavy metals could adversely affect aquatic organisms resulting in retarded growth, reduced reproduction and abnormal response to the opposite sex (Ezemonye and Enuneku, 2006).

Plankton, larval fish, and bottom dwelling organisms are strongly affected by oil spills which in turn may have negative consequences on human health from consuming contaminated seafood. Oil spill destroyed farmlands, pollute groundwater or drinking water and could caused drawbacks in fishing off the coastal waters. Sediments samples recording values greater than 5000 $\mathrm{mg} / \mathrm{kg}$ requires bioremediation. Although values obtained were below $5000 \mathrm{ppm}$. These contaminations in turn affect man since he would drink water and feed on the contaminated fish and bottom dwelling organisms.

\section{Conclusion}

The research work studied the effect of oil pollution on the environment of two oil bearing Niger Delta communities. The results showed that after about one year of oil spill and subsequent clean-up, the ecological effects was still noticed on the environmental components (water and sediment). This implied that the post clean-up exercise was not effective and natural attenuation was not able to restore the environment to its original state. There is the need to regularly monitor such environment receiving crude oil spill/discharge since crude oil can destroy the rich biodiversity of the Niger Delta and human lives.

\section{COMPETING INTERESTS}

The authors declare that they have no competing interests.

\section{AUTHORS' CONTRIBUTIONS}

Sampling was carried out by all the authors. The chemical analyses and interpretations were carried out by the chemists DFO and FEO, while the microbiological analyses and interpretations were done by the microbiologist LET-A. All results and interpretations including quality assurance/quality control measures were assessed by all authors. There was active 
participation of all the authors in this research work.

\section{REFERENCES}

Aisien FA, Hymore FK, Ebewele RO. 2006. Comparative absorption of crude oil from fresh and marine water using recycled rubber. J. Envir. Engrg., 132(9): 1078-1081.

Akpofure EA, Efere ML, Ayawei P. 2000. The adverse effects of crude oil spills in the Niger Delta. Urhobo Historical Society, 1: 21-33.

Almeda R, Wambaugh Z, Wang Z, Hyatt C, Liu Z, Buskey EJ. 2013. Interactions between zooplankton and crude oil: toxic effects and bioaccumulation of polycyclic aromatic hydrocarbons. PLoS ONE, 8(6): e6712.

American Public Health Association (APHA), America Water Works Association (AWWA) and Water Environmental Federation (WEF). 2005. Standard Methods for the Examination of Water and Wastewater (21 $1^{\text {th }}$ edn). APHA, AWWA and WEF.

Chase DA, Edwards DS, Qin G, Wages MR, Willming MM, Anderson TA, Maul JD. 2013. Bioaccumulation of petroleum hydrocarbons in fiddler crabs (Uca minax) exposed to weathered MC-252 crude oil alone and in mixture with an oil dispersant. Science of the Total Environment, 444: 121-127.

Culbertson JB, Valiela I, Olsen YS, Reddy CM. 2008. Effects of field exposure to 38 year old residual petroleum hydrocarbons on growth, condition index, and filtration rate of ribbed mussel, Geukensia demmissa. Environmental Pollution, 154: 312-319.

Department of Petroleum Resources (DPR). 2011. Environment Guidelines and Standards for the Petroleum Industry in Nigeria (EGASPIN) (Revised Edition). DPR.

Dural M, Goksu MZL, Ozak AA. 2007. Investigation of heavy metal levels in economically important fish species captured from the Tuzla Lagoon. Food Chem., 102: 415-421.

Egborge ABM. 2000. Wild life, In: Government, Oil Companies, the People and the Niger Delta Environment $\left(4^{\text {th }}\right.$ convocation lecture of Delta State University, Abraka). BEN Miller Books Nigeria Ltd.; 55-61.

Ezemonye LIN, Enuneku AA. 2006. Stage dependent acute toxicity of exposure of Bufo maculatus and Ptychadena bibroni tadpoles to cadmium. Journal of Applied Science and Technology, 11(1,2): 78-82.

Ezemonye LIN, Ogeleka DF, Okieimen FE. 2009. Lethal toxicity of industrial detergent on bottom dwelling sentinels. Int. J. Sediment Res., 24: 478-482.

Federal Environmental Protection Agency (FEPA). 1991. Federal Republic of Nigeria: (S.18), National Environment Protection (Effluent Limitation) Regulations. S19. National environmental protection (Pollution abatement in industries and facilities generating wastes) Regulations 1991. Federal Republic of Nigeria Official Gazette., 78 (42). pp38.

Federal Ministry of Environment Abuja, Nigerian Conservation Foundation Lagos, WWF UK and CEESP-IUCN Commission on Environmental, Economic, and Social Policy, Niger Delta Resource Damage Assessment and Restoration Project. 2006.

Hayat S, Javed M, Razzaq, S. 2007. Growth performance of metal stressed major carps viz. Catla catla, Labeo rohita and Cirrhina mrigala reared under semiintensive culture system. Pakistan Vet. J., 27(1): 8-12.

Heng LY, Mokhtar MB, Rusin S. 2004. The bioaccumulation of trace essential metals by the freshwater snail Turritella sp. found in the rivers of Borneo East Malaysia. Journal of Biological Science, 4(4): 441 - 444.

Hussain SM, Javed M, Javid A, Javid T, Hussain N. 2011. Growth responses of Catla catla, Labeo rohita and Cirrhina 
mrigala during chronic exposure of iron. Pak. J. Agri. Sci., 48: 239-244.

Ijah UJJ, Antai SP. 2003. Removal of Nigerian light crude oil in soil over a 12month period. International Biodeterioration \& Biodegradation., 51 (2): 93-99.

International Institute of Tropical Agriculture (IITA). 1984. Selected methods for soil and plant analysis. IITA press, Ibadan, Nigeria. Manual Series., 1: 10-50.

Jack IR, Fekarurhorho JK, Igwe FU, Okorosaye OK. 2005. Determination of total hydrocarbon levels in some marine organisms from some towns within River State in Nigeria. Journal of Applied Science and Environmental Management, 9(3): 59-61.

Kanchanamayoon W, Tatrahun N. 2008. Determination of polycyclic aromatic hydrocarbons in water samples by solid phase extraction and gas chromatography. World J. Chem., 3(2): 51-54.

Landis WG, $\mathrm{Yu}$ MH. 2004. Introduction to Environmental Toxicology; Impact of Chemicals upon Ecological Systems (3rd edn). Lewis Publishers: Boca Raton, Florida.

Nwilo CP, Badejo TO. 2004. Management of oil dispersal along the Nigerian coastal areas. Department of Survey \& Geoinformatics, University of Lagos, Lagos.

Nwilo CP, Badejo TO. 2005a. Impacts and management of oil spill pollution along the Nigerian coastal areas. Department of Survey \& Geoinformatics, University of Lagos, Lagos.

Nwilo CP, Badejo TO. 2005b. Oil spill problems and management in the Niger Delta. International Oil Spill Conference, Miami, Florida, USA.

Ogeleka, DF, Ezemonye LIN, Okieimen FE. 2010. Toxicity of industrial chemicals on biological indicators in water, sediment and soil. International Research Journal of Biotechnology, 1(3): 37-43.
Oyem A. 2001. Christian call for action on Nigerian Oil Spill. Sage-Oxford's Christian Environmental Group.

Pyagbara SL. 2007. The adverse impacts of oil pollution on the environment and wellbeing of a local indigenous community: The Experience of the Ogoni people of Nigeria. United Nations (UNIES). PFII/2007/WS.3/6.

Rauf A, Javed M, Ubaidullah M. 2009. Heavy metal levels in three major carps (Catla Catla, Labeo Rohita and Cirrhina Mrigala) from the River Ravi, Pakistan. Pakistan Vet. J., 29(1): 24-26.

Shell Petroleum Development Company (SPDC). 2006. People and the environment. Annual Report, 1995. The Guardian Newspaper, Oil 50 years on. pp16.

Tawari-Fufeyin P, Ekaye, SA. 2007. Fish species diversity as indicator of pollution in Ikpoba river, Benin City, Nigeria. Rev. Fish Biol. Fisheries., 17: 21-30.

Twumasi Y, Merem E. 2006. GIS and remote sensing applications in the assessment of change within a coastal environment in the Niger Delta region of Nigeria. International Journal of Environmental Research \& Public Health., 3(1): 98106.

Uyigue E, Agho M. 2007. Coping with climate change and environmental degradation in the Niger Delta of Southern Nigeria. Community Research and Development Centre Nigeria (CREDC).

Vinodhini R, Narayanan M. 2008. Bioaccumulation of heavy metals in organs of fresh water fish Cyprinus carpio (Common carp). Int. J. Environ. Sci. Tech., 5(2): 179-182.

Yilmaz F, Ozdemir N, Demirak A, Tuna AL. 2007. Heavy metal levels in two fish species Leuciscus cephalus and Lepomis gibbosus. Food Chem., 100: 830-835. 